\title{
Assessment of severity of acute pancreatitis over time
}

\author{
FLORINA-ALEXANDRA COFARU ${ }^{1,2}$, SILVIA NICA ${ }^{1,2}$, CARMEN FIERBINȚEANU-BRATICEVICI $^{1,2}$ \\ 1 "Carol Davila” University of Medicine and Pharmacy Bucharest, Romania \\ ${ }^{2}$ University Emergency Hospital Bucharest, Romania
}

\begin{abstract}
In recent years there has been an increase in the incidence of acute pancreatitis worldwide. In spite of efforts to improve the treatment and care of patients with acute pancreatitis, to develop imaging investigations and interventional diagnostic and treatment techniques and to facilitate patients' access to them, acute pancreatitis continues to be associated with significant mortality and morbidity, and the treatment of patients suffering from this disease entails significant costs for healthcare systems.

Researchers are in a permanent quest to get to a global consensus for stratifying the severity of acute pancreatitis. We need this in order to offer the proper management for each patient diagnosed with this condition and to improve hospital and health system strategies.

Over the years, it has been attempted to develop algorithms to support a swift assessment of patients with acute pancreatitis with a prediction of disease severity as close to reality as possible for optimal management. This has led to the development of classifications of severity and severity scores. These require a permanent updating to keep up with the technical and technological developments involved in investigating and treating the patient and encompassing the most recent studies.

The goal of this paper is to go through these classifications and scores, emphasizing factors that should be taken into account, and reflecting upon their utility and upon the necessity of improving them.
\end{abstract}

Key words: pancreatitis, acute necrotizing pancreatitis, acute hemorrhagic pancreatitis, pancreatic function test, alcohol.

\section{INTRODUCTION}

The annual incidence of acute pancreatitis is around 4.9 to $35 / 100,000$ persons with a mortality of $5 \%$ [1]. Around $20 \%$ of the patients with acute pancreatitis develop a severe form of disease. Specialized care centres may encounter high mortality rates, $10-15 \%$, in the case of severe acute pancreatitis [2]. Therefore, pancreatitis raises many concerns in terms of classifications regarding severity. In the last 50 years many changes have been made in point of understanding the physiopathology of acute pancreatitis, diagnosis and therapy. Conservative treatment and alternatives to surgical technics started to replace the classical surgical treatment in selected cases of pancreatitis. The aim of this paper is to revise the criteria used over time for risk stratification of patients with acute pancreatitis, according to the severity and the need for admission in intensive care units.

\section{SCORING SYSTEMS IN PREDICTING THE SEVERITY OF ACUTE PANCREATITIS}

Starting from the $19^{\text {th }}$ century several attempts have been made in order to classify the forms of acute pancreatitis. Worth mentioning Marseilles, Cambridge and Marseilles-Rome classifications. Cases of acute pancreatitis were split into mild and severe forms. Severe forms were considered accompanied by multiple system organ failure. Severe forms associated complications, local or systemic, like: phlegmon, pseudocyst, abscess [3].

In 1974 a pancreatic surgeon, John Ranson, introduced Ranson Criteria which were used to predict prognostic and mortality risk in patients with acute pancreatitis. Some criteria are collected at admission (age, glucose, LDH, AST, WBC) and some are collected at 48 hours from admission (serum calcium, base deficit, haematocrit, BUN, sequestrated fluid and hypoxemia). A score $\geq 3$ indicates severe acute pancreatitis. Also a score $\leq 1$ predicts low chances of organ failure and complications and low mortality rates. Sensibility and specificity of the score are low. After 1993, about 110 studies concluded that the Ranson score had a low predictive value. The advantage of Ranson Criteria is that the patients with severe forms of pancreatitis are ruled out. Yet, the 48 hours for collecting data slows the adoption of optimal therapeutic behaviours in severe cases, which represents a disadvantage. Another inconvenient is the fact that the score can 
be used only once, in the initial moment of the disease [3, 4].

In 1981, William Knaus, an American intensivist developed the APACHE score (Acute Physiology and Chronic Health Evaluation). The score was revised four times, but the second revision, APACHE II, is the most used, universally accepted. APACHE II score includes about 14 criteria like: past history of organ failure or deficiency (NYHA IV, chronic kidney disease that requires dialysis, cirrhosis), temperature, mean arterial pressure, age, respiratory rate, heart rate, white blood cell count, sodium, potassium, arterial blood $\mathrm{pH}$, creatinine, haematocrit, Glasgow Coma Scale, blood oxygenation. The worst results from the first 24 hours are taken into account. Although the APACHE score is intended to evaluate the mortality in intensive care unit, it has high sensitivity for predicting complicated acute pancreatitis. Basically the score involves the chronic medical status of the patient and the acute illness in order to assess severity. This score has a good negative predictive value and a poor positive predictive value. It is considered that a score $<8$ implies a mortality rate $<4 \%$ and a score $>8$ implies a mortality of $11-18 \%$. Major advantages of this score are: data can be collected in 24 hours in comparison with Ranson criteria where 48 hours were needed and the score can be used daily for monitoring the evolution of the disease. A disadvantage is the complexity of the score (too many variables and some of them may not be available outside ICU) and the incapacity of differentiating between interstitial and necrotic acute pancreatitis and between sterile or infected necrosis $[2,5,6,7]$.

In France, in 1983, Le Gall et al. established The Simplified Acute Physiology Score model (SAPS). This is a version of the APACHE score. It was made public and updated immediately after APACHE score and is usually used in intensive care unit in comparison with the APACHE score. It predicts mortality with a sensitivity of $87.5 \%$ and a specificity of $77.8 \%$. SAPS takes into account 12 variables documented in the first 24 hours of admission, the age and the comorbidities. It is suggested in literature to associate different scores such as SAPS II and Balthazar score to increase the accuracy of the prognosis $[8,9]$.

The Systemic Inflammatory Response Syndrome (SIRS) criteria were as follows: temperature $>38^{\circ} \mathrm{C}$ or $<36^{\circ} \mathrm{C}$, heart rate $>90 \mathrm{bpm}$, respiratory rate $>24$ breaths/minute, leucocytosis $>12,000 / \mathrm{mm}^{3}$.
For a systemic inflammatory response syndrome, two criteria are needed. Fulfilling the four criteria pointed to a severity diagnosis. Pediatric criteria were different, being related to normal physiological values based on age [10].

BISAP score (Bedside Index for Severity in Acute Pancreatitis) also predicts mortality risk. Data used from the very first 24 hours are: urea, Glasgow Coma Scale, evidence of SIRS, age and presence of pleural effusion. A null score would associate a mortality of less than $1 \%$, while patients with a maximum score of five have a mortality rate of $22 \%$. The validation cohort showed similar performance for predicting mortality for BISAP score comparative to APACHE II score, but it was not validated for predicting the length of hospital stay, the need for intensive care or intervention. The advantage of the score is that this uses fewer variables, which makes this score simpler to use, more adequate for emergency department [11-13].

Glasgow Pancreatitis Score was elaborated by Blamley et al. in 1984 . The system predicts the severity of acute pancreatitis by considering the following items: Partial Pressure of Oxygen $\left(\mathrm{PO}_{2}\right)$ on room air $<60 \mathrm{mmHg}$, age $>55$, serum albumin $<32 \mathrm{~g} / \mathrm{l}$, serum LDH $>600$ units/L, serum urea nitrogen $>45 \mathrm{mg} / \mathrm{dL}$, serum calcium $<8 \mathrm{mg} / \mathrm{dL}$, WBC $>15000$, blood glucose $>180 \mathrm{mg} / \mathrm{dl}$. A score $\geq 2$ reveals a severe case. A score $\geq 3$ shows that the patient is likely to need ICU admission [14].

In 2007 a retrospective cohort study of a large multicentre intensive care database developed a new outcome prediction score - The Pancreatitis Outcome Prediction Score (POP Score) for highrisk patients. There were studied 2,462 patients from 159 UK intensive care units. The score identifies the patients that may benefit from more aggressive management [15].

An algorithm for rapid initial stratification of non severe disease was elaborated - the Harmless Acute Pancreatitis Score (HAPS). The aim of the score is to identify the patients with a first attack of acute pancreatitis who do not need intensive care unit admission. The score included only three parameters: no guarding and/or rebound tenderness, a normal haematocrit level and a normal serum creatinine level. The advantage of the score is that patients with mild form of acute pancreatitis that don't need intensive care or even inpatient treatment can be identified in the first 30 minutes after admission. This score is very simple to perform and may save hospital costs $[16,17]$. 
Other scores predict the severity of acute pancreatitis according the organ failure as: Goris Score, Marshall Score, Modified Marshall System, Bernard Organ Failure Score, SOFA Score, Logistic organ dysfunction system score. So, modified Marshall System use the next parameters: the respiratory status $\left(\mathrm{PaO}_{2} / \mathrm{FiO}_{2}\right)$, renal status (serum creatinine) and cardiovascular status (systolic blood pressure). The maximum score for each system is 4 . A score $\geq 2$, for any of the systems, for over 48 hours defines persistent organ failure, while the same score for less than 48 hours is considered as transient organ failure. The Modified Marshall System is mentioned in the Revised Atlanta Classification [3]. The advantages of this system are: the ability to stratify the severity of the disease, it is simple to use, and it can be applied across international centres.

The Sequential Organ Failure Assessment Score (SOFA score), first known as sepsis related organ failure assessment score, sums up six different scores, a score for each of the following systems: cardiovascular, hepatic, urinary, respiratory, coagulation and nervous. The score is used to evaluate the organ failure, therefore predicting the clinical outcomes of critically ill patients. This score was improved, thus Quick SOFA Score (qSOFA Score) was elaborated in February 2016. The qSOFA Score suggests high risk of poor outcome in patients with suspected infection. This score is much simpler because it involves only three clinical criteria (low blood pressure $\leq 100 \mathrm{mmHg}$, respiratory rate $\geq 22$ breaths/min and any altered mental state, Glasgow Coma Scale (GCS $\leq 14)$. If the score is 2 or 3 , the patient is close to the onset of infection and has a higher risk of death and a probability for a longer ICU stay. Therefore, The Third International Consensus Definitions for Sepsis and Septic Shock (Sepsis-3) considers SIRS criteria definitions of sepsis have too many limitations and need to be replaced with qSOFA to identify patients with infection who are likely to be septic [18].

In parallel, severity scores based on data from imaging investigations have been developed Balthazar Score, CT severity index (CTSI), Modified CTSI. The presence and the extension of the pancreatic necrosis associated to the inflammatory changes are correlated with the severity of acute pancreatitis. The CT scan may show pancreatic necrosis and inflammatory changes. In this case there is a high probability of complications and unfavourable evolution. The result of the CT scan influences the therapeutic decision.
The promoter of these scores was the Balthazar score. It evaluates the prognosis based on the appearance of CT scan. The imaging describes 5 classes: $\mathrm{A}$ - normal pancreas, $\mathrm{B}$ - enlarged pancreas with an intrapancreatic fluid collection, $\mathrm{C}$ - class B changes associated with peripancreatic fat infiltration, $\mathrm{D}$ - changes in class $\mathrm{C}$ are added a single remote liquid collection and $\mathrm{E}$ - the occurrence encountered in class B and at least 2 remote collections or the presence of pancreatic or peripancreatic gas bubbles. Classes $\mathrm{A}$ and $\mathrm{B}$ have a favourable evolution. Classes C, D and E may evolve with complications such as pancreatic abscesses $[19,20]$.

The CT Severity Index sums the Balthazar score and the extent of pancreatic necrosis. When grading the extent of pancreatic necrosis, for no necrosis there is score 0 , for necrosis $\leq 30 \%$ - score 2 , necrosis between $30 \%$ and $50 \%$ - score 4 and necrosis $\geq 50 \%$ - score 6 . Thus, the maximum CTSI score is 10 . A score between $0-3$ reveals a mild acute pancreatitis. CTSI from 4-6 inclines to moderate acute pancreatitis. 7-10 points raises concern for severe acute pancreatitis. Studies show a good correlation between clinical scores and imaging scores, therefore imaging is not necessary for assessing severity of pancreatitis [8]. Modified CTSI was evaluating pancreatic inflammation ( 2 points for intrinsic pancreatic abnormalities, 4 for fluid collection or peripancreatic fat necrosis), pancreatic necrosis ( 2 points for less than 30\% necrosis and 4 for more than $30 \%$ ) and extra pancreatic complications ( 2 points). Mild acute pancreatitis would sum up 0-2 points, moderate acute pancreatitis $4-6$ points and severe acute pancreatitis encounters a score of $8-10[19,21,22]$.

Until 2002 there were no scoring systems for children for predicting severity in acute pancreatitis. DeBanto conducted a study on 301 admissions of children with acute pancreatitis, following eight parameters (age, weight, white blood cell count, LDH, calcium at 48 hours, albumin at 48 hours, fluid sequestration in 48 hours, rise in urea in 48 hours). The new score - Pediatric Acute Pancreatitis Score had a better sensitivity and a better negative predictive value than Ranson and Glasgow scores, while the specificity and positive predictive value were closer to Ranson and Glasgow scores [23].

The Atlanta Classification of 1992 was the first attempt of a global consensus regarding acute pancreatitis and of establishing a clear classification system. It relied on Ranson Criteria and on Apache Score. Two revisions, 2007 and 2013 followed. The 
Revised Atlanta Classification includes definitions for diagnostic of acute pancreatitis, definitions of complications and of the morphology changes encountered in acute pancreatitis. Two types of pancreatitis are described: interstitial and necrotic. Three levels of severity of the disease are considered: mild, moderately severe, and severe. Mild acute pancreatitis would not develop organ failure and complications and would resolve during the first week. The moderately severe form means acute pancreatitis with transient organ failure (developed and limited during the first 48 hours) with or without complications. Local complications included fluid collections, colonic necrosis, thrombosis of the splenic and portal veins, gastric dysfunction. In the moderately severe form, acute pancreatitis could lead to decompensation of chronic conditions such as coronary disease, chronic obstructive pulmonary obstruction, diabetes, congestive cardiac failure or chronic liver disease. Severe acute pancreatitis associates persistent organ failure (develops and persists over 48 hours). This revision relies on Marshall Score and SIRS. Pancreatic enzymes were important for diagnosis, but not for predicting severity. Predicting severity in the first week is based on clinical parameters. Thus, if a patient with acute pancreatitis would develop persistent systemic inflammatory response syndrome should be classified temporarily as having severe acute pancreatitis. The gastrointestinal bleeding is no longer a criteria for organ failure [4, 9]. The scope of this classification is to identify rapidly patients with a bad prognostic and apply an aggressive management, if necessary consider transfer to ICU or transfer to a tertiary medical centre. The advantage of this classification is the evaluation of the acute pancreatitis as a dynamic process, the level of severity can differ in time. A disadvantage of this classification is that it does not point out the patients that may need surgical treatment.

Therefore, in 2012, a new international classification of acute pancreatitis - Determinant Based Classification was developed. It was a new concept based of the multidisciplinary contribution of all researchers involved in clinical research on acute pancreatitis. The determinants of the severity of acute pancreatitis could be local, such as pancreatic necrosis or peripancreatic necrosis, or systemic, such as organ failure. Organ failure is defined as a SOFA score $\geq 2$ or if inotropic support is initiated with or without serum creatinine higher than $2 \mathrm{mg} / \mathrm{dl}$ with or without $\mathrm{PaO}_{2} / \mathrm{FiO}_{2}<300 \mathrm{mmHg}$. Mild acute pancreatitis requires the absence of necrosis or organ failure. Moderate form is characterized by sterile necrosis with or without transient organ failure. Severe acute pancreatitis requires infected necrosis or persistent organ failure. The fourth group is critical acute pancreatitis and sums up both infected necrosis and organ failure, with the highest mortality, respectively $43 \%$. A disadvantage of this classification is that it does not document the dynamics of organ failure. Determinant Based Classification does not include definitions of fluid collections and does not take into account gastric dysfunction, portal or splenic vein thrombosis, and colonic necrosis as local complications, and does not take into consideration systemic complication in the classification of severity $[3,9]$.

\section{COMPARISON OF SCORING SYSTEMS}

Scoring systems are used simultaneously, therefore comparison studies are developed. Sometimes studies can validate and compare to other scoring systems or with previous versions of the same system.

In 2013, Nawaz H. and colleagues compared The Atlanta Classification, Revised Atlanta Classification and Determinant Based Classification studying 256 patients with acute pancreatitis. Clinical outcomes like mortality, ICU admission, need for intervention, length of stay in ICU, total hospital stay were evaluated. Both Revised Atlanta Classification and Determinant Based Classification appeared to be superior to the previous Atlanta Classification. Revised Atlanta Classification seem to better predict length of hospital stay and Determinant Based Classification predicted better the need for intervention [24].

In 2014 a Spanish study involved 459 patients with 543 acute pancreatitis episodes. The study concluded that both systems, Revised Atlanta Classification and Determinant Based Classification were accurate in classifying the severity and the predicted clinical outcomes were similar [25].

The Chinese comparison study from the same year, conducted on 553 patients, aimed to validate the Revised Atlanta Classification and to compare it to Atlanta Classification. It was emphasized the need for assessing clinical outcome of patients with severe acute pancreatitis with infected necrosis separately from those without infected necrosis $[3,9]$.

Yet, none of these classification can predict the progression from one severity group to another. 
In 2002, Ranson Score, APACHE II and APACHE III were compared in a study and proved the same accuracy in predicting the clinical outcomes. 153 patients were assessed prospectively [26].

In 2010, BISAP score proved itself accurate, clinically relevant, easy to work with and with similar prediction value as the traditional systems (Ranson, APACHE, CTSI) [26].

A retrospective study in a tertiary care centre in China that enrolled 155 patients evaluated the predictive capacity of BISAP score, APACHE II, Ranson score and the Revised Atlanta Classification. BISAP turned out to be a promising way of prognostication, but needed further multicentre validation [27].

In 2015, a Chinese meta-analysis that involved twelve cohorts from ten different studies concluded that BISAP outperformed in specificity, in comparison to Ranson Score and APACHE II, but had a suboptimal sensitivity for mortality and for severity of acute pancreatitis, the same as SAPS [7, 28].

An Iranian study compared SAPS II with APACHE scores in terms of predicting short term hospital mortality regarding surgical ICU patients. 202 patients admitted in ICU after surgery were assessed. Discrimination (ability to classify patients into survivors and non-survivors) was great for APACHE II score and acceptable for APACHE III and SAPS II. So was calibration (how closely estimated probabilities of mortality correlate with the observed mortality). Therefore, APACHE II has a better ability to predict mortality in surgical patients admitted in ICU after surgery than APACHE III or SAPS II [29].

There are three scores that include SIRS criteria - BISAP score, Japanese Severity Score for acute pancreatitis and Pediatric JPN score. The latter uses the pediatric SIRS criteria.

The age threshold that would influence the severity of acute pancreatitis varies according to the score used (Ranson score $\geq 55$ years, BISAP score $\geq 60$ years, Glasgow score $\geq 55$ years, APACHE score $\geq 44$ years, The Japanese Criteria $\geq 70$ years, SAPS score $\geq 40$ ).

APACHE and SAPS take into account the previous health status of the patient.

The renal status is the most common variable and it is considered by all the severity scoring systems except qSOFA. Renal status implies laboratory tests like serum creatinine, serum urea, serum sodium, serum potassium or measure of the urine output.

Most of the scores determine patients at risk, while HAPS identifies patients that are not at risk.

\section{DISCUSSIONS}

The scoring systems that need 48 hours for collecting data delay the therapeutic decision. Therefore, scoring systems that need only 24 hours or less are preferable. Scores that can be used daily help to closely monitor the evolution of the disease and the evolution of the severity of the disease.

All the scoring systems are limited because they can only quantify each factor, whether is clinical, biological or imagistic in an equal manner. Interactions between factors, the capacity of amplifying one another's effect is not yet established by any of the scores. Also none of the scores predict which complication and when might appear.

No laboratory test can accurately predict, on its own, the severity of acute pancreatitis. Yet, a $\mathrm{CRP}>150 \mathrm{mg} / \mathrm{L}$ measured at 48 hours is important for discriminating patients with severe acute pancreatitis $[9,30,31,32]$.

Scoring systems based on imaging factors are not useful for predicting severity in the initial phase of the disease. They can be used to supplementary evaluate the patient.

Scoring systems that rely on organ failure evaluation are the most accurate

The recommendations of the American Association of Gastroenterology are the following: the prediction of the severity of the disease should be done using the APACHE Score (a severe form of acute pancreatitis is considered for an APACHE score $\geq 8$ ), patients with severe acute pancreatitis have to be considered for admission in ICU, patients with severe acute pancreatitis and signs of organ failure in the first 72 hours should undergo a CT scan to evaluate the level of pancreatic necrosis and a level of CRP $\geq 150 \mathrm{mg} / \mathrm{l}$ in the first 48 hours should be taken into account when evaluating a patient with acute pancreatitis $[2,33]$.

There is a consistent need of classifications of severity of disease and severity assessment scores for optimal triage, universal language regarding acute pancreatitis and for providing more accurate information to patients and their families.

An optimal triage, to determine the priority of patients' treatments based on severity of their condition is an action that needs to be thought both from a micro perspective (patient centred perspective) and a macro perspective (care unit perspective, hospital perspective). Therefore, a correct and rapid triage would promote fast access to proper investigations, treatments and interventions (sometimes lifesaving) and would place the patient in the right place to be (medical care unit, surgical care unit or 
intensive care unit or referral to an advanced care centre).

Since all medical actions (investigation, treatment, intervention, admission in different care units of the hospital) are money-related, proper management of the patient leads to optimal costs. For example, if a patient with a mild form of disease and a good prognostic is admitted in intensive care unit, the costs would be raised, or if a patient with a severe form of disease and bad prognostic is admitted in a medical care unit, the negative evolution of the disease might escalade, the patient would eventually be admitted to ICU with higher financial costs and sometimes with the loss of the patient.

In order to treat acute pancreatitis thoroughly, with good results, there is a need to study worldwide, to capture the particularities of different populations, geographical areas, the economic and climate influences. These studies need comparison. Therefore, there is a need for a common language, common terms, definitions, scores, and classifications of severity of the disease.

Developed countries lead the world in medical research: the United States of America, European countries, Australia, China, Japan [34]. These have the financial means and interests. The Asian and African continents are struggling to improve medical research. For example the African continent is considered to be a good environment for conducting clinical trials because of the diversity of the population, because most of the population has not been exposed to pharmaceutically drugs and because on the continent are encountered a variety of diseases considered endemic for developing countries [35].

When developing classifications and scores of severity of disease it is important to study both males and females and decide upon differences and conduct different studies on adults and children. There are ethical issues that complicate research studies on women such as pregnancy, menstruation. Ethical issues are involved also in studying children and risks are to be taken into account such as the radiation effect. Moreover, there is also the reluctance of parents to subscribe their children for research.

\section{CONCLUSIONS}

Web-based communication from primary care centres to secondary and tertiary care centres has major importance in the study of acute pancreatitis. This should be encouraged by national, continental and international societies for surgery, gastroenterology, emergency medicine, intensive care and primary medicine. Primary and secondary care centres should be involved in research, in order to gain more experience and to keep the physicians updated and interested in the subject. Nevertheless, multicentre studies that collect data from primary, secondary and tertiary care centres proved to be most reliable. Collected data for studies, documentation of particular situations or cases, updates for guidelines and new research results should be communicated to all care centres.

Each clinic should develop a comparative study between the available scores in order to choose the ones that are more appropriate for that particular place. Professional experience, service experience, tools availability are factors that influence the decision upon which score is applicable in a certain care centre.

Future updates of the scores for the severity of acute pancreatitis or the new scores that will be developed should take into account other variables such as sex, altitude, race, the local incidence of nosocomial infections for a more accurate prediction of the outcome and for advancing towards customized healthcare.

În ultimii ani s-a înregistrat o creștere a incidenței pancreatitei acute la nivel mondial. În ciuda eforturilor de a îmbunătăți tratamentul şi ingrijirea pacienților cu pancreatită acută, de a dezvolta investigații imagistice și tehnici de diagnostic și tratament intervenționale și de a facilita accesul pacienților la acestea, pancreatita acută continuă să fie asociată cu o mortalitate și o morbiditate semnificative și tratamentul pacienților care suferă de această boală implică costuri ridicate pentru sistemele de sănătate.

Cercetătorii sunt într-o permanentă încercare de a ajunge la un consens în ceea ce priveşte clasificarea severității pancreatitei acute. Avem nevoie de acest lucru pentru a oferi un management adecvat pentru fiecare pacient diagnosticat cu această afecțiune și pentru a îmbunătăți strategiile de acțiune la nivel de spital și de sistem de sănătate. 
De-a lungul anilor s-a încercat dezvoltarea unor algoritmi care să susțtină o evaluare rapidă a pacienților cu pancreatită acută cu o prezicere a gravității bolii cât mai aproape de realitate pentru un management optim. Aceasta a dus la dezvoltarea clasificărilor și scorurilor de severitate. Acestea necesită o actualizare permanentă pentru a fi la curent cu evoluțiile tehnice și tehnologice implicate în investigarea și tratarea pacientului și înglobarea celor mai recente studii.

Scopul acestei lucrări este parcurgerea acestor clasificări şi scoruri, subliniind factorii care ar trebui să fie luați în considerare și importanţa reflectării la utilitatea lor și la necesitatea îmbunătățirii acestora.

Correspondence to: Florina Alexandra Cofaru, M.D, University Emergency Hospital Bucharest - 169 Splaiul Independenței street, sector 5, Bucharest

Tel.: 0742452780

E-mail: florina.cofaru@drd.umfcd.ro, cfierbinteanu@yahoo.com

Conflict of interest disclosure: The authors declare that there are not conflicts of interest.

\section{REFERENCES}

1. SANTHI S.V., Etiology of acute pancreatitis, https://www.uptodate.com/contents/etiology-of-acute-pancreatitis, date of access: 22/07/19.

2. VASILE D., Pancreatita acută severă - Diagnosticul de severitate. In: Pancreatita acută severă, Editura Universitara "Carol Davila", Bucharest, 2017:155.

3. TALUKDAR R., VEGE S.S., Classifications Systems for the Severity of Acute Pancreatitis, Pancreapedia: Exocrine Pancreas Knowledge Base, 2015, https://www.pancreapedia.org/node/9006, date of access: 10/08/19.

4. DABROWSKI A., Classification of acute pancreatitis, Department of Gastroenterology and Internal Medicine, Medical University of Bialystok, Poland, www.eage-epsg.org/past-courses/2010-6th-eage-prague/lectures-pdf/soubory/A_02, date of access: $24 / 07 / 19$.

5. BELL D.J., SMITH H. et al., APACHE score, Radiopaedia, https://radiopaedia.org/articles/apache-score-2, date of access: 10/08/19.

6. KNAUS W.A., ZIMMERMAN J.E., WAGNER D.P., DRAPER E.A., LAWRENCE D.E., APACHE - acute physiology and chronic health evaluation: a physiologically based classification system, Crit. Care. Med., 1981, 9(8):591-7 https://www.ncbi. nlm.nih.gov/pubmed/7261642, date of access: 10/08/19.

7. KNAUS W.A., DRAPER E.A., WAGNER D.P., ZIMMERMAN J.E., APACHE II: a severity of disease classification system, Crit. Care. Med., 1985, 13(10):818-29, https://www.ncbi.nlm.nih.gov/pubmed/3928249, date of access: 10/08/19.

8. FERREIRA A.F., BARTELEGA J.A., URBANO H.C.A., SOUZA I.K.F., Acute pancreatitis gravity predictive factors: which and when to use them?, Arq. Bras. Cir. Dig., 2015, Jul.-Sep., 28(3): 207-11. https://www.ncbi.nlm.nih.gov/pmc/articles/ PMC4737365/, date of access: 10/08/19.

9. LEPPANIENI A., TOLONEN M., TARASCONI A., SEGOVIA-LOHSE H., GAMBERINI E., KIRKPATRICK A.W., 2019 WISES guidelines for the management of severe acute pancreatitis, World Journal of Emergency Surgery, 2019, 14:27. https://www.ncbi.nlm.nih.gov/pmc/articles/PMC6567462/, date of access: 11/02/2020.

10. MOFIDI R., DUFF M.D., WIGMORE S.J., MADHAVAN K.K., GARDEN O.J., PARKS R.W., Association between early systemic inflammatory response, severerity of multiorgan dysfunction and death in acute pancreatitis, The British Journal of Surgery, 2006, Jun, 93(6):738-44, https://www.ncbi.nlm.nih.gov/pubmed/16671062, date of access: 11/02/2020.

11. GAO W., YANG H.X., MA C.E., The Value of BISAP Score for Predicting Mortality and Severity in Acute Pancreatitis: A Systematic Review and Meta-Analysis, PLoS One, 2015, 10(6), https://www.ncbi.nlm.nih.gov/pmc/articles/PMC4474919/, date of access: 10/08/19.

12. PAPACHRISTOU G.I., MUDDANA V., YADAV D., O'CONNELL M., SANDERS M.K., SLIVKA A. et al., Comparison of BISAP, Ranson's, APACHE-II and CTSI Scores in Predicting Organ Failure, Complications and Mortality in Acute Pancreatitis, American Journal of Gastroenterology, 2010. 1055(2):435-441, https://www.ncbi.nlm.nih.gov/pubmed/19861954, date of access: 10/08/19.

13. HARIDAS T.V., ASIF IQBALL I.K., A prospective study of the bedside index for severity in acute pancreatitis (BISAP) score in predicting severity and prognosis of acute pancreatitis, International Surgery Journal, 2019, Feb., 6(2):570-573, https://www. researchgate.net/publication/330705198_A_prospective_study_of_the_bedside_index_for_severity_in_acute_pancreatitis_BISAP_ score in predicting severity and prognosis of acute pancreatitis, date of access: $10 / 0 \overline{8} / 2020$.

14. BLAM̄EY S.L., IMRIE C.W., O’NEILL J., GILMOUR W.H., CARTER D.C., Prognostic factors in acute pancreatitis, Gut, 1984, 25:1340-1346, https://www.ncbi.nlm.nih.gov/pmc/articles/PMC1420197/pdf/gut00397-0014.pdf, date of access: 10/08/19.

15. HARRISON D.A., D'AMICO G., SINGER M., The Pancreatitis Outcome Prediction (POP) Score: a new prognostic index for patients with severe acute pancreatitis, Crit. Care. Med., 2007, 35(7):1703-8, https://www.researchgate.net/publication/6309441 The_Pancreatitis_Outcome_Prediction_POP_Score_A_new_prognostic_index_for_patients_with_severe_acute_pancreatitis, date of access: $10 / 08 / 19$. 
16. LANKISCH P.G., WEBER-DANY B., HEBEL K., MAISONNEUVE P., LOWENFELS A.B., The Harmless Acute Pancreatitis Score: A Clinical Algorithm for Rapid Initial Stratification of Nonsevere Disease, Clinical Gastroenterology and Hepatology, 2009, 7(6):702-5, https://www.sciencedirect.com/science/article/pii/S1542356509001402, date of access: 10/08/19.

17. NG D.W.K., GAO Y., FURQAN M.S., BONNEY K.G., KOW A.W.C., MADHAVAN K., IYER S.G., Validation of Harmless Acute Pancreatitis Score (HAPS) in a Tertiary Asian Medical Institute, 2019, 21(2):S406-S407, https://www.hpbonline.org/ article/S1365-182X(19)32849-7/fulltext, date of access: 11/02/2020.

18. SINGER M., DEUTSCHMAN C.S., SEYMOUR C.W., SHANKAR-HARI M., ANNANE D., BAUER M. et al., The Third International Consensus Definitions for Sepsis and Septic Shock (Sepsis-3), 2016, 315(8):801-10. https://www.ncbi.nlm.nih.gov/ pubmed/26903338, date of access: 10/08/19.

19. FORTIN F., CUETE D. et al., CT severity index in acute pancreatitis. Radiopaedia. https://radiopaedia.org/articles/ct-severityindex-in-acute-pancreatitis-3?lang=gb, date of access: 11/08/19.

20. LAUTZ T.B., TURKET G., RADHAKRISHNAN J., WYERS M., CHIN A.C., Utility of the computed tomography severity index (Balthazar score) in children with acute pancreatitis. Journal of Pediatric Surgery. 2012. 47:1185-1191. https://www.academia. edu/29078805/Utility_of_the_computed_tomography_severity_index_Balthazar_score_in_children_with_acute_pancreatitis, date of access: $11 / 08 / 19$.

21. BROWN A., SHETTY A., Modified CT severity index, Radiopaedia, https://radiopaedia.org/articles/modified-ct-severity-index, date of access: 11/08/19.

22. TAKEDA K., YOKOE M., TAKADA T., KATAOKA K., YOSHIDO M., GABATA T. et al., Assessment of severity of acute pancreatitis according to new prognostic factors and CT grading, Journal of Hepato-Biliary-Pancreatic Sciences, 2010. 17(1):37-44, https://link.springer.com/article/10.1007/s00534-009-0213-4 date of access: 10/08/19.

23. DEBANTO J.R., GODAY P.S., PEDROSO M.R., IFTIKCHAR R., FAZEL A., NAYYAR S. et al., Acute pancreatitis in children, The American Journal of Gastroenterology, 2002, 97(7):1726-31, https://www.ncbi.nlm.nih.gov/pubmed/?term= Midwest\%20Multicenter\%20Pancreatic\%20Study\%20Group\%5BCorporate\%20Author\%5D, date of access: 11/08/2019.

24. NAWAZ H., MOUNZER R., YADAV D., YABES J.G., SLIVKA A., WHITCOMB D.C. et al., Revised Atlanta and determinant-based classification: application in a prospective cohort of acute pancreatitis patients, The American Journal of Gastroenterology, 2013, 108(12):1911-7, https://www.ncbi.nlm.nih.gov/pubmed/24126632, date of access: 11/08/19.

25. ACEVEDO-PIEDRA N.G., MOYA-HOYO N., REY-RIVEIRO M., GIL S., SEMPERE L., MARTINEZ J. et al., Validation of the determinant-based classification and revision of the Atlanta classification systems for acute pancreatitis, Clinical Gastroenterology and Hepatology, 2014, 12(2):311-6, https://www.ncbi.nlm.nih.gov/pubmed/23958561, date of access: 11/08/19.

26. CHATZICOSTAS C., ROUSSOMOUSTAKAKI M., VLACHONIKOLIS I.G., NOTAS G., MOUZAS I., SAMONAKIS D. et al., Comparison of Ranson, APACHE II and APACHE III scoring systems in acute pancreatitis, Pancreas, 2002, 25(4):331-5, https://www.ncbi.nlm.nih.gov/pubmed/12409825, date of access: 11/08/19.

27. PAPACHRISTOU G.I., MUDDANA V., YADAV D., O'CONNELL M., SANDERS M.K., SLIVKA A. et al., Comparison of BISAP, Ranson's, APACHE-II, and CTSI scores in predicting organ failure, complications, and mortality in acute pancreatitis, The American Journal of Gastroenterology, 2010, 105(2):435-41, https://www.ncbi.nlm.nih.gov/pubmed/19861954, date of access: $11 / 08 / 19$.

28. ZHANG J., SHAHBAZ M., FANG R., LIANG B., GAO C., GAO H. et al., Comparison of the BISAP scores for predicting the severity of acute pancreatitis in Chinese patients according to the latest Atlanta classification, Journal of Hepato-BiliaryPancreatic Sciences, 2014, 21(9):689-94, https://www.ncbi.nlm.nih.gov/pubmed/24850587, date of access: 11/08/19.

29. GILANI M.T., RAZAVI M., AZAD A.M., A comparison of Simplified Acute Physiology Score II, Acute Physiology and Chronic Health Evaluation II and Acute Physiology and Chronic Health Evaluation III scoring system in predicting mortality and length of stay at surgical intensive care unit, Nigerian Medical Journal, 2014, 55(2):144-47, https://www.ncbi.nlm.nih.gov/pmc/ articles/PMC4003718/, date of access: 11/08/19.

30. LEAL C., ALMEIDA N., Predicting Severity in Acute Pancreatitis: A Never-Ending Quest..., Portuguese Journal of Gastroenterology, 2019, 26:232-234, https://www.karger.com/Article/Pdf/499680, date of access: 10/02/2020.

31. CARDOSO F.S., RICARDO L.B., OLIVIERA A.M., HORTA D.V., PAPOILA A.L., DEUS J.R., C-Reactive Protein at 24 hours after hospital admission may have relevant prognostic accuracy in acute pancreatitis: A retrospective cohort study, GE Port. J. Gastroenterol., 2015, Apr., 22(5):198-203.

32. KOMOLAFE O., PEREIRA S.P., DAVIDSON B.R., GURU-SAMY K.S., Serum C-reactive protein, procalcitonin, and lactate dehydrogenase for the diagnosis of pancreatic necrosis, Cochrane Data-base Syst. Rev., 2017, Apr., 4(4):CD012645.

33. CROCKETT S.D., WANI S., GARDNER T.B., YTTER Y.F., BARKUN A.N., American Gastroenterological Association Institute Management of Acute Pancreatitis, 2018, March, 154(4):1096-1101, https://www.gastrojournal.org/article/S0016-5085 (18)30076-3/abstract, date of access: 10/02/2020.

34. YEE V., VANLANG C., PAREJA E., What countries have led the world in medical research and innovation during the time period between 1995 and 2014?, Quora, 2015, 2018, https://www.quora.com/What-countries-have-lead-the-world-in-medicalresearch-and-innovation-during-the-time-period-between-1995-and-2014, date of access: 11/08/2019.

35. PATRA S.K., Africa hosts very few clinical trials. Why this is bad for innovation, The Conversation, 2018, http:// theconversation.com/africa-hosts-very-few-clinical-trials-why-this-is-bad-for-innovation-97390, date of access: 11/08/19.

Received August $13^{\text {th }} 2019$ 